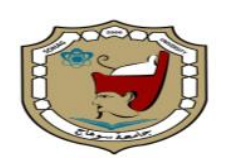

\title{
Knowledge, Attitudes, and Practices towards COVID-19 among Health Care Workers in Primary Health Care Units Dar El Salam, Sohag, Egypt.
}

\author{
Abd El-Nassir S Mohammed \\ Department of Community Medicine, Al-Azhar Faculty of Medicine, Assiut, Egypt
}

\begin{abstract}
Background: COVID-19 pandemic is a worldwide and social emergency that requires the application of strict measures to prevent the rapid spread of the disease. Health Care Workers (HCWs) compliance to control measures can be affected and determined by their Knowledge, Attitudes, and Practices (KAP) towards the virus.

Aim of work: To evaluate the knowledge, attitude, and practice among HCWs towards COVID 19.

Methods: A cross-sectional study was done to evaluate KAP among HCWs towards COVID 19. This study involved a sample of online Health care workers in which they shared by sending an invitation link across the available social media seeking to react and answer the questionnaire (Survey Monkey tool) was sent

Results: The majority of respondents were female 82 (77.4\%). Most of the 66 (64.4\%) were nurses, $28(26.4 \%)$ were pharmacists and 10 (9.4\%) were physicians. Mean age and standard deviation (SD) $30.10 \pm 5.25$ years. About $(79.2 \%),(84.8 \%)$ and $(91.7 \%)$ of the participants (nurses, pharmacists, and physicians) were within the accepted knowledge range respectively. The majority of the HCWs had an accepted attitude $(78.6 \%-100 \%)$ towards the successful control of COVID-19, majority of the HCWs had healthy practice and preventive measures given by local health care authorities $(85.3 \%-100 \%-100 \%)$ of the nurses, pharmacists and physicians respectively.

Conclusion and recommendations: Our results ensured the need to assess the KAP towards COVID-19 among the HCWs (nurses, pharmacists, and physicians). This will induce a promising attitude and encourage healthy practice.

Keywords: COVID-19, Knowledge, Attitude, Practice, HCWs
\end{abstract}

\section{Introduction}

At the beginning of the year 2020, after the appearance of many cases with a respiratory infection (pneumonia) of unknown origin in Wuhan, Hubei, China, a novel coronavirus was discovered by doctors, they called it SARS-CoV-2 then COVID-19 (1). The SARS-CoV-2 disease is suggested to have animal origins (probably from the Huanan seafood market in Wuhan). It has a similar genome structure $(96 \%)$ like bat coronavirus, supposing that, emerging as a bat-borne virus (2). Also, an intermediate animal reservoir such as the pangolin was suggested to be involved in its transmission to humans, but efforts to determine an intermediate host seem to fail until now $(3,4)$.

COVID-19 consider a health emergency that affects the respiratory system and have social effects all over the world. $(5,6)$. It is one of the Beta coronaviruses similar to Severe Acute Respiratory Syndrome Human coronavirus 
(SARS HCV) and The Middle-East Respiratory Syndrome Human coronavirus (MERS HCoV) $(7,8)$. They come by acute onset high body temperature, easy fatigability, dry cough, chest pain, muscle pain, and difficult breathing. About ten to twenty percent of the patients developed severe manifestations, which are characterized by acute respiratory distress syndrome $(5,6)$.

Data told us the overall mortality rate from COVID-19 infection ranges from two up to five percent all over the world and less than those of SARS (9.5\%), and MERS (34.4\%). In addition, COVID-19 persist to infect the risky groups, so that it requires the need to move from purely responsiveness activeties to include proactive treatment of the infectious disease $(5,9)$.

According to the World Health Organization (WHO) surveillance draft in the early of 2020, any passenger to Wuhan, Hubei Province in China, fifteen days prior to the onset of manifestations is suspected to be a COVID-19 patient until proved otherwise $(10,11)$.

COVID-19 pandemic was confirmed to be spread in Egypt by the $14^{\text {th }}$ of February 2020. On the $1^{\text {st }}$ of May 2020, there have been 5,895 confirmed cases, 1,460 cured and 406 were dead (12).

On the $11^{\text {th }}$ of March, 2020, the World Health Organization (WHO) declared, the novel Corona Virus Disease (COVID-19) as a pandemic after it has spread in more than 110 countries all over the world. COVID-19 pandemic completed its course, crossing beyond the continents invading most of the globe, and affect almost all countries and territories even those which are very far from its starting origin (China) $(13,14)$

Poor knowledge, bad attitudes, and unhealthy practices in relation to disease protection are shared to elevate the risk of transmission and unfavorable impacts of the disease (15). To ensure effective preventive practice and optim- um preparedness regarding respiratory tract infection prevention during COVID- 19 pandemic knowledge, attitude, and healthy practices (KAP) are essential. Information about COVID 19 considers of significant value in provideng the required strategies to be carried out. Moreover, these would enhance and evaluate the presently available programs as well as recognize possible interventions to improve the behavioral and attitudinal changes. Positive attitude and behavioral changes are driven by the level of knowledge and perceptions towards preventive practices (16).

\section{Aim of work:}

To evaluate the knowledge, attitude, and practice of nurses, pharmacists, and physicians of the primary health care units in Dar El Salam, Sohag. To increase the homogeneity of the sample we choose HCWs from primary health care units.

\section{Subject and methods \\ 1- Study Design and setting}

A cross-sectional study was conducted from the first to the fifteenth of May 2020. As regards the nature of the COVID-19 mode of transmission, I used an online questionnaire sheet for data collection. HCWs of primary health care units in Dar El Salam district, Sohag were involved by sending a link to the questionnaire seeking to answer it. Survey Monkey tool was used to make a link and KAP questionnaire for data collection (17). A Google survey was created and the survey link was sent to HCWs via the obtainable social media channels.

\section{2- Sampling Method}

The sample was taken in a consecutive manner that means all respondents of health care workers (nurses, pharmacists and physicians) working in Dar El Salam were included in the study. We choose that site because Researches not 
frequent in Dar El Salam so, primary health care were included 106 from 173 (61.3\%) HCWs.

\section{Study Population}

All HCWs (nurses, pharmacists, and physicians) in Dar El Salam primary health care. workers were involved and invited to participate in the study by sending the link of the questionnaire to them. The overall HCWs are 216 (nurses, pharmacists, and physicians) they distributed all over these units, 70 were males and 146 were females, 43 out of $216 \mathrm{HCWs}$ had vacationed in the form of (laying, income improvement, travel, and child care). So, the actual force is $173 \mathrm{HCWs}$. divided into three categories (98 nurses, 53 pharmacists, and 22 physicians) distributed upon 28 primary health care units. The poor response to participate in the study attributed to fear of the health care workers from the formal assessment of their KAP by their executives this opinion was supported by requesting of many participants the confidentiality of their data.

\section{Study Tool}

The survey consisting of twenty variables based on KAP survey forms. This form was modified and translated into the Arabic language. The questionnaire had personal and KAP questions. personal data including age, sex, and occupation (17). KAP had seventeen questions including clinical manifestations, transmission methods, and COVID-19 control. These questions were answered on a Yes/No, true/false, and "I don't know" measures, true or false according to their answer is it correct or not. For knowledge questionns, incorrect or do not know (the incorrect answers) were given a 0 score, while 1 point was given for choosing (the correct answer). The total knowledge score ranged from zero to twelve. More score indicating a better knowledge about COVID-19. For the attitude and practice sections, a score of 1 was given for choosing the answer reflecting agreement on attitude or healthy practice, and 0 was given for choosing the answer reflecting the disagree on attitude or unhealthy practice. Practices are scored 1 and 0 for doing the healthy act or not respectively.

Another method of the assessment showed that knowledge scores above $60 \%$ were regarded as having satisfactory knowledge, while those who scored below $60 \%$ were considered as unsatisfactory knowledge (18). Attitude scores of $80 \%$ and above were grouped as a good attitude, while HCWs within the range of $60-$ less than $80 \%$ were considered moderate and score below $60 \%$ had an unacceptable attitude (19). For the practice section, scores $>80 \%$ were classified as having acceptable preventive practice, while those with scores $<80 \%$ were considered to have unacceptable preventive practice (20). Also, the percentage score was used to assess the level of $\operatorname{KAP}(21,22)$.

\section{5- Ethics considerations}

The data were kept confidential and the results did not identify the respondents personally.

\section{Data Analysis}

Data entry and statistical analysis were performed using the Statistical Package for Social Sciences (SPSS) version 20.0 and presented by using mean and standard deviation respondents' age. Categorical variables were presented by using frequency and percentage using chi-square test in which significance level less than or equal $5 \%$ (P-value $\leq .05)$. Descriptive statistics were used to determine personal factors and KAP scores.

\section{Results}

\section{Personal Data}

The ages of the respondents ranged from between 21 and 44 years, with 
mean age and standard deviation (SD) $30.10 \pm 5.25$ years. The majority of the respondents were females $82(77.4 \%)$. Most of the respondents 66 (64.4\%) were nurses, $28(26.4 \%)$ were pharmacists and $10(9.4 \%)$ were physicians. The summary of the characteristics is shown in Table1.

\section{Assessment of HCWs Knowledge towards COVID 19.}

Respondents knowledge about COVID19 symptoms was good (100\%), less common symptoms of COVID-19 $(70.6 \%, 82.1 \%$, and $100 \%)$ for nurses, pharmacists, and physicians respectively, also most of HCWs had concepts that there is no definite treatment of COVID-19 but supportive care $(63,2 \%$, $100 \%$, and $100 \%$ ) for nurses, pharmacists and physicians respectively. (78\%, $89.3 \%$ and $70 \%$ ) for nurses, pharmacists, and physicians respectively HCWs think that all patients with COVID-19 will not become severely ill. In general, out of 106 participants, $(79.2 \%),(84.8 \%)$, and (91.7) had satisfyactory total knowledge scores respectively. Most of them awarded the causes, risk determinants, and transmission of the virus as shown in Table 2.

\section{HCWs Attitude Towards Preven- tion of COVID-19}

Most of the HCWs had a positive attitude $(78.6 \%-100 \%)$ towards COVID19 will be successfully controlled while a few percent $(10 \%-21.4 \%)$ of the participants had a negative attitude. On the other hand, HCWs had a positive attitude $(85.3 \%-100 \%)$ towards our trusting about we can overcome the problem of the COVID-19 virus but a few percent $(14.3 \%-14.7 \%)$ of the respondents had a negative attitude based on total attitude score. The total attitude score percentage $(92.65 \%$ -
$82.15 \%-95 \%$ ) for nurses, pharmacists, and physicians respectively.

\section{HCWs' COVID-19 Prevention Practice}

Table (4) illustrates that, responses of the participant's group regarding the various protecting practices using 3 questions. The total practice score percentage of the respondents is $(82.33 \%$ $84.5 \%-100 \%$ ) for nurses, pharmacists, and physicians respectively. (92.6\%71,4\% -100\%) Among nurses, pharmacists and physicians respectively had good practice towards visiting crowded areas and (7.4\% - 28,6- 0\%) among nurses, pharmacists and physicians respectively had a poor practice towards going to any crowded areas recently. The majority of HCWs wore personal protective equipment when going out of the home $(69.1 \%-82.1 \%-100 \%)$ of the nurses, pharmacists, and physicians respectively). also, the majority of $\mathrm{HC}$ Ws had practiced protective methods given by health authorities $(85.3 \%$ $100 \%-100 \%$ ) of the nurses, pharmacists, and physicians respectively).

\begin{tabular}{|c|l|l|}
\hline Variables & No. & $\%$ \\
\hline Gender & 24 & 22.60 \\
Male & 82 & 77.40 \\
Female & & \\
\hline Occupation & 68 & 64.20 \\
Nurses & 28 & 26.40 \\
Pharmacists & 10 & 9.40 \\
Physicians & \multicolumn{2}{|l|}{} \\
\hline Mean age & $30.10 \pm 5.25$ \\
\end{tabular}

Table (No. 1): Characteristics of the study respondents $(n=106)$. 
SOHAG MEDICAL JOURNAL Vol. 25 No. 1 Jan 2021
Knowledge, Attitudes, and Practices towards COVID-19 Abd El-Nassir S Mohammed

\begin{tabular}{|c|c|c|c|c|c|c|c|}
\hline \multirow[t]{2}{*}{ Question } & \multirow[t]{2}{*}{ Occupation } & \multicolumn{2}{|c|}{$\begin{array}{l}\text { Correct } \\
\text { answer }\end{array}$} & \multicolumn{2}{|c|}{$\begin{array}{l}\text { False } \\
\text { answer }\end{array}$} & \multirow[t]{2}{*}{$\chi^{2}$} & \multirow[t]{2}{*}{$\begin{array}{l}\mathrm{P} \\
\text { value }\end{array}$} \\
\hline & & No & $\%$ & \begin{tabular}{|l} 
No \\
\end{tabular} & $\%$ & & \\
\hline $\begin{array}{l}\text { What are the chief } \\
\text { manifestations of COVID-19? }\end{array}$ & $\begin{array}{l}\text { Nurses } \\
\text { Pharmacist } \\
\text { Physician }\end{array}$ & $\begin{array}{l}68 \\
28 \\
10\end{array}$ & $\begin{array}{l}100 \\
100 \\
100\end{array}$ & $\begin{array}{l}0 \\
0 \\
0\end{array}$ & $\begin{array}{l}0 \\
0 \\
0\end{array}$ & & \\
\hline $\begin{array}{l}\text { Are runny nose, and sneezing } \\
\text { less in persons infected with } \\
\text { COVID-19 virus than a common } \\
\text { cold? }\end{array}$ & $\begin{array}{l}\text { Nurses } \\
\text { Pharmacist } \\
\text { Physician }\end{array}$ & $\begin{array}{l}48 \\
23 \\
10\end{array}$ & $\begin{array}{l}70.6 \\
82.1 \\
100\end{array}$ & $\begin{array}{l}20 \\
5 \\
0\end{array}$ & $\begin{array}{l}29.4 \\
17.9 \\
.00\end{array}$ & 4.877 & .050 \\
\hline $\begin{array}{l}\text { What is the definitive treatment } \\
\text { of COVID-19? }\end{array}$ & $\begin{array}{l}\text { Nurses } \\
\text { Pharmacist } \\
\text { Physician } \\
\end{array}$ & $\begin{array}{l}43 \\
28 \\
10 \\
\end{array}$ & $\begin{array}{l}63.2 \\
100 \\
100 \\
\end{array}$ & $\begin{array}{l}25 \\
0 \\
0 \\
\end{array}$ & $\begin{array}{l}36.8 \\
0.00 \\
0.00 \\
\end{array}$ & 18.282 & .001 \\
\hline $\begin{array}{l}\text { Whom of the patients with } \\
\text { COVID-19 will not transform } \\
\text { into severe illness? }\end{array}$ & $\begin{array}{l}\text { Nurses } \\
\text { Pharmacist } \\
\text { Physician }\end{array}$ & $\begin{array}{l}53 \\
25 \\
7\end{array}$ & $\begin{array}{l}78 \\
89.3 \\
70 \\
\end{array}$ & $\begin{array}{l}15 \\
3 \\
3 \\
\end{array}$ & $\begin{array}{l}22 \\
10.7 \\
30 \\
\end{array}$ & 9.862 & .043 \\
\hline $\begin{array}{l}\text { Can Feeding or contacting with } \\
\text { wild animals cause infection } \\
\text { with COVID-19? }\end{array}$ & $\begin{array}{l}\text { Nurses } \\
\text { Pharmacist } \\
\text { Physician }\end{array}$ & $\begin{array}{l}47 \\
20 \\
8\end{array}$ & $\begin{array}{l}69.1 \\
71.4 \\
80\end{array}$ & \begin{tabular}{|l|}
21 \\
8 \\
2
\end{tabular} & $\begin{array}{l}30.9 \\
28.6 \\
20\end{array}$ & 4.881 & .300 \\
\hline $\begin{array}{l}\text { Are the patients with COVID-19 } \\
\text { able to transmit the virus to } \\
\text { others when the patient } \\
\text { temperature is normal? }\end{array}$ & $\begin{array}{l}\text { Nurses } \\
\text { Pharmacist } \\
\text { Physician }\end{array}$ & $\begin{array}{l}50 \\
3 \\
8\end{array}$ & $\begin{array}{l}73.5 \\
10.7 \\
80\end{array}$ & $\begin{array}{l}18 \\
25 \\
2\end{array}$ & $\begin{array}{l}26.5 \\
89.3 \\
20\end{array}$ & 35.295 & .000 \\
\hline $\begin{array}{l}\text { Can COVID-19 transmit via } \\
\text { respiratory droplets of patients } \\
\text { or not? }\end{array}$ & $\begin{array}{l}\text { Nurses } \\
\text { Pharmacist } \\
\text { Physician } \\
\end{array}$ & $\begin{array}{l}50 \\
28 \\
10 \\
\end{array}$ & $\begin{array}{l}73.5 \\
100 \\
100 \\
\end{array}$ & $\begin{array}{l}18 \\
0 \\
0 \\
\end{array}$ & $\begin{array}{l}26.5 \\
0.00 \\
0.00 \\
\end{array}$ & 12.116 & .002 \\
\hline $\begin{array}{l}\text { Can Populations wear personal } \\
\text { protective equipment to be } \\
\text { protected from the virus? }\end{array}$ & $\begin{array}{l}\text { Nurses } \\
\text { Pharmacist } \\
\text { Physician }\end{array}$ & $\begin{array}{l}44 \\
28 \\
10\end{array}$ & $\begin{array}{l}64.7 \\
100 \\
100\end{array}$ & $\begin{array}{l}24 \\
0 \\
0\end{array}$ & $\begin{array}{l}35.3 \\
0.00 \\
0.00\end{array}$ & 17.337 & .000 \\
\hline $\begin{array}{l}\text { May youngest individuals not } \\
\text { need to take measures to prevent } \\
\text { the infection by the virus? }\end{array}$ & $\begin{array}{l}\text { Nurses } \\
\text { Pharmacist } \\
\text { Physician }\end{array}$ & $\begin{array}{l}56 \\
25 \\
9 \\
\end{array}$ & $\begin{array}{l}82.4 \\
89.3 \\
90 \\
\end{array}$ & $\begin{array}{l}12 \\
3 \\
1 \\
\end{array}$ & $\begin{array}{l}17.6 \\
10.7 \\
10 \\
\end{array}$ & 43.96 & .000 \\
\hline $\begin{array}{l}\text { Can COVID-19 } \\
\text { prevent via avoiding } \\
\text { areas? }\end{array}$ & $\begin{array}{l}\text { Nurses } \\
\text { Pharmacist } \\
\text { Physician } \\
\end{array}$ & $\begin{array}{l}51 \\
21 \\
8 \\
\end{array}$ & $\begin{array}{l}75 \\
75 \\
80 \\
\end{array}$ & $\begin{array}{l}17 \\
7 \\
2 \\
\end{array}$ & $\begin{array}{l}25 \\
25 \\
20 \\
\end{array}$ & 6.082 & .193 \\
\hline $\begin{array}{l}\text { Are management and isolation } \\
\text { of the patients effectively } \\
\text { prevent transmission of the } \\
\text { virus? }\end{array}$ & $\begin{array}{l}\text { Nurses } \\
\text { Pharmacist } \\
\text { Physician }\end{array}$ & $\begin{array}{l}68 \\
28 \\
10\end{array}$ & $\begin{array}{l}100 \\
100 \\
100\end{array}$ & $\begin{array}{l}0 \\
0 \\
0\end{array}$ & $\begin{array}{l}0.00 \\
0.00 \\
0.00\end{array}$ & & \\
\hline $\begin{array}{l}\text { What can we do with Individuals } \\
\text { contacted with a patient? }\end{array}$ & $\begin{array}{l}\text { Nurses } \\
\text { Pharmacist } \\
\text { Physician }\end{array}$ & $\begin{array}{l}68 \\
28 \\
10\end{array}$ & $\begin{array}{l}100 \\
100 \\
100\end{array}$ & $\begin{array}{l}0 \\
0 \\
0\end{array}$ & $\begin{array}{l}0.00 \\
0.00 \\
0.00\end{array}$ & & \\
\hline Percentage of knowledge & $\begin{array}{l}\text { Nurses } \\
\text { Pharmacist } \\
\text { Physician }\end{array}$ & & & & & & \\
\hline
\end{tabular}

Table (No. 2): Assessment of HCWs Knowledge towards COVID 19. 
SOHAG MEDICAL JOURNAL

Vol. 25 No. 1 Jan 2021
Knowledge, Attitudes, and Practices towards COVID-19 Abd El-Nassir S Mohammed

\begin{tabular}{|c|c|c|c|c|c|c|c|}
\hline & \multirow[t]{2}{*}{ Occupation } & \multicolumn{2}{|c|}{ Agree } & \multicolumn{2}{|c|}{ Disagree } & \multirow[t]{2}{*}{$\chi^{2}$} & \multirow{2}{*}{$\begin{array}{l}\mathrm{P} \\
\text { value }\end{array}$} \\
\hline & & No & $\%$ & No & $\%$ & & \\
\hline $\begin{array}{l}\text { COVID-19 will be overcome } \\
\text { lately }\end{array}$ & $\begin{array}{l}\text { Nurses } \\
\text { Pharmacist } \\
\text { Physician }\end{array}$ & $\begin{array}{l}68 \\
22 \\
9\end{array}$ & $\begin{array}{l}100 \\
78.6 \\
90\end{array}$ & $\begin{array}{l}0 \\
6 \\
1\end{array}$ & $\begin{array}{l}0.00 \\
21.4 \\
10.0\end{array}$ & 27.303 & .000 \\
\hline $\begin{array}{l}\text { We will succeed in the battle } \\
\text { against the virus }\end{array}$ & $\begin{array}{l}\text { Nurses } \\
\text { Pharmacist } \\
\text { Physician }\end{array}$ & $\begin{array}{l}58 \\
24 \\
10\end{array}$ & $\begin{array}{l}85.3 \\
85.7 \\
100\end{array}$ & $\begin{array}{l}10 \\
4 \\
0\end{array}$ & $\begin{array}{l}14.7 \\
14.3 \\
0.00\end{array}$ & 1.683 & .431 \\
\hline Percentage of attitude & $\begin{array}{l}\text { Nurses } \\
\text { Pharmacist } \\
\text { Physician }\end{array}$ & $\begin{array}{l}92.6 \\
82.1 \\
95.0\end{array}$ & & & & & \\
\hline
\end{tabular}

Table (No. 3): HCWs Attitude Towards Prevention of COVID-19.

\begin{tabular}{|c|c|c|c|c|c|c|c|}
\hline & \multirow[t]{2}{*}{ Occupation } & \multicolumn{2}{|l|}{ Yes } & \multicolumn{2}{|l|}{ No } & \multirow[t]{2}{*}{$\chi^{2}$} & \multirow{2}{*}{$\begin{array}{l}\mathrm{P} \\
\text { value }\end{array}$} \\
\hline & & No & $\%$ & No & $\%$ & & \\
\hline $\begin{array}{l}\text { Have you visit any crowded areas } \\
\text { recently? }\end{array}$ & $\begin{array}{l}\text { Nurses } \\
\text { Pharmacist } \\
\text { Physician }\end{array}$ & $\begin{array}{l}63 \\
20 \\
10\end{array}$ & $\begin{array}{l}92.6 \\
71.4 \\
100\end{array}$ & $\begin{array}{l}5 \\
8 \\
0\end{array}$ & $\begin{array}{l}7.4 \\
28.6 \\
0.00\end{array}$ & 9.842 & .007 \\
\hline $\begin{array}{l}\text { Have you worn personal prote- } \\
\text { ctive equipment when going out } \\
\text { recently? }\end{array}$ & $\begin{array}{l}\text { Nurses } \\
\text { Pharmacist } \\
\text { Physician }\end{array}$ & $\begin{array}{l}47 \\
2310\end{array}$ & $\begin{array}{l}69.1 \\
82.1 \\
100\end{array}$ & $\begin{array}{l}21 \\
5 \\
0\end{array}$ & $\begin{array}{l}30.9 \\
17.9 \\
0.00\end{array}$ & 5.406 & .050 \\
\hline $\begin{array}{l}\text { Are you Pract-icing preventive } \\
\text { procedures advised by the health } \\
\text { authorities? }\end{array}$ & $\begin{array}{l}\text { Nurses } \\
\text { Pharmacist } \\
\text { Physician }\end{array}$ & $\begin{array}{l}64 \\
28 \\
10\end{array}$ & $\begin{array}{l}85.3 \\
100 \\
100\end{array}$ & $\begin{array}{l}4 \\
0 \\
0\end{array}$ & $\begin{array}{l}5.9 \\
0.00 \\
0.00\end{array}$ & 2.323 & .313 \\
\hline Percentage of practice & $\begin{array}{l}\text { Nurses } \\
\text { Pharmacist } \\
\text { Physician }\end{array}$ & & & & & & \\
\hline
\end{tabular}

Table (No. 4): HCWs' COVID 19 Prevention active.

\section{Discussion}

This study considers one of the earliest online cross-section studies to determine the KAP towards CORONA virus in between HCWs. In this study, (79.2\%), $(84.8 \%)$ and $(91.7)$ of the participants (nurses, pharmacists, and physicians) had good knowledge towards CORONA virus, which compared with a study done in China the study population are experts from local health departments, agriculture departments, Centers for Disease Control and Prevention (CDCs), hospitals, and journalists who have experience of SARS. where about $70 \%$ of study populations had good knowledge. Other researches from different sites supposed that good knowledge in the control of infection is a promising indicator of better practice $(23,24)$, also, they focused on the great difference in disease knowledge may lead to uncertainties and non stringent control methods (25). Also, a study in Uganda shows that the percentage knowledge score of the health care workers were $82,4 \%$ (good knowledge) (26).

In my study, the majority of the respondents had trusted that COVID-19 will be overcome $100 \%, 78.6 \%$ and $90 \%$ for nurses, pharmacist, and physicians respectively and had a certainty about us sure that we can win the fight against the disease $85.3 \%, 85.7 \%$, and $100 \%$ respectively. That confidence in fact due to healthy practice with the majority of the participants reporting not 
go to crowded areas and wearing personal protective equipment when they going out of their residence. In contrast; a study showed that about seventeen percent of HCW trusted that wearing personal protective equipment like face masks considered of no value against COVID-19 (27). Although, medical face mask for the prevention of SARS-CoV-2 spread is a matter of current research. This study has identified factors related to KAP. The findings are beneficial for policy-makers to fast consider the need for a comprehensive specific group target health education program for COVID-19 prevention and control. The finding of good knowledge among HCWs is a good predictor of positive impact initiative to involve the community in a fight for COVID-19.

In our study, The percentage total practice score of the participants is $(82.33 \%$ $-84.5 \%-100 \%$ ) for nurses, pharmacists, and physicians respectively had a good practice in contrast to a study in Uganda illustrates that just over $70 \%$ of the HCWs had healthy practices toward COVID-19 especially those aged 40 years or more (26).

\section{Conclusion and Recommendati- on}

The male to female ratio of the participant was 24/82 Most of them 66 $(64.4 \%)$ were nurses, 28 (26.4\%) were pharmacists and $10(9.4 \%)$ were physicians with mean age and standard deviation (SD) $30.10 \pm 5.25$ year. The majority of them had good knowledge which is more among physicians also, most of the HCWs had a positive attitude towards the successful control of COVID-19 and the majority of them had healthy practices and preventive measures given by local health care authorities. Our findings ensured the need to publish the KAP towards COVID-19 among the health care staff.
This will encourage an optimistic attitude and maintaining healthy practices that transmit to the general population across the health learning programs and mass media. A community-based health education program about COVID-19 is beneficial and essential to overcome the disease. Go on of skilled education is needed among HCWs in Egypt to elevate the level of knowledge of HCWs also, avoiding negative attitudes and encouraging positive preventive and healthy practices. We advise follow-up researches including teaching and non-teaching hospitals all over the country.

Limitation of the study: (1) Data collection cannot be done face to face due to COVID 19 pandemic.

(2) It is difficult to take formal approval from any responsible individual.

\section{References}

1- Zhu, N. Zhang, D. Wang, W. Li, X. Yang, B. Song, J. Zhao, X. Huang, B. Shi, $\mathbf{W}$ and $\mathbf{L u}, \mathbf{R}$. A novel coronavirus from patients with pneumonia in china, 2019. N. Engl. J. Med. 2020; 382: $727-$ 733.

2- Zhou, P. Yang, X. Wang, X. Hu, B. Zhang, L. Zhang, W. Si, H. Zhu, Y. Li, B, and Huang, C. A pneumonia outbreak associated with a new coronavirus of probable bat origin. Nature. 2020; 579: 270-273.

3- Velavan, T, and Meyer, C. The COVID-19 epidemic. Trop. Med. Int. Health. 2020; 25: 278-280.

4- The John Hopkins University of Medicine. Coronavirus resource center. Available online: https://coronavirus.jhu. edu/map. 2020.

5- The Novel Coronavirus Pneumonia Emergency Response Epidemiology Team. The epidemiological characteristics of an outbreak of 2019 novel coronavirus diseases (COVID-19) in China. Chin J Epidemiol. 2020; 41:145-151.

6- Chen, N. Zhou, M. Dong, X. Qu, J. Gong, $\mathbf{F}$ and Han, Y. Epidemiological and clinical characteristics of 99 cases 
of 2019 novel coronavirus pneumonia in Wuhan, China: a descriptive study. Lancet. 2020; 395:507-513.

7- Elfiky, A. Mahdy, S and Elshemey, W. Quantitative structure-activity relationship and molecular docking revealed a potency of anti-hepatitis $\mathbf{C}$ virus drugs against human coronaviruses. Journal of Medical Virology. 2017; 89(6): 1040-1047.

8- Chan, J. Lau, S. To, K. Cheng, V. Woo, $P$ and Yuen, K. Middle East respiratory syndrome coronavirus: another zoonotic betacoronavirus causing SARS-like disease. Clinical microbiology reviews.2015; 28(2): 465-522.

9- Munster, V. Koopmans, M. van Dormagen, N. van Riel, D, and de Wit, E. Novel Coronavirus Emerging in China - Key Questions for Impact Assessment. N Engl J Med. 2020; 382:692-694.

10- Bogoch, I. Watts, A. Thomas Bachli, A. Huber, C. Kraemer, $M$ and Khan, K. Pneumonia of Unknown Etiology in Wuhan, China: Potential for International Spread Via Commercial Air Travel. Journal of Travel Medicine. 2020;1-3.

11- WHO. Surveillance case definitions for human infection with the novel coronavirus (nCoV): interim guidance v1, January 2020: World Health Organization. 2020.

12- Egypt reports. highest single-day coronavirus death toll at 20 , plus 248 new infections on Monday at AlAhram (retrieved 28 April 2020)

13- WHO. Novel coronavirus (2019nCoV) situation report-12. https://www.who.int/docs/defaultsource/coronaviruse/situation reports/2020020 2020.

14- Wang, C. Horby, P. Hayden, F and Gao, G. A novel coronavirus outbreak of global health concern. Lancet. 2020; 395(10223):470-473.

15- Wahab, F. Abdullah, S. Abdullah, J. Jaafar, H. Noor, S. Mohammad, W. Yusoff, A. Tharakan, J. Bhaskar, S and Sangu, M. Updates on knowledge, attitude and preventive practices on tuberculosis among healthcare workers. Malays. J. Med Sci. MJMS. 2016; 23:25.

16- Larson, E. Bryan, J. Adler, L and Blane, C. A multifaceted approach to changing handwashing behavior. Am. J. Infect. Control. 1997; 25:3-10.

17- www.surveymonkey.com

18- Yusof, A. Rahman, $\mathbf{N}$ and Haque, M. Knowledge, attitude, and practice toward food poisoning among food handlers and dietetic students in a public university in Malaysia. J. Pharm. Bioallied Sci. 2018; 10:232.

19- Shafei, M. Sulong, M. Yaacob, N. Hassan, H. Mohamad, W. Daud, A. Ismail, $\mathbf{Z}$ and Abdullah, $\mathbf{M}$. Seroprevalence of leptospirosis among town service workers in the northeastern state of Malaysia. Int. J. Collab. Res. Intern. Med. Public Health. 2012; 4: 395.

20- Arbiol, J. Orencio, P. Nomura, H. Takahashi, $Y$ and Yabe, $M$. Knowledge, attitude and practices towards leptospirosis among lakeshore communities of Calamba and Los Baños, Laguna, Philippines. Agriculture. 2016; 6: 18.

21- Yimer, S. Holm-Hansen, $C$ and Bjune, G. Assessment of knowledge and practice of private practitioners regarding tuberculosis control in Ethiopia. J Infect Dev Ctries. 2012; 6(1):13-19.

22- Vandan, N. Ali, M. Prasad, R and Kuroiwa, C. Assessment of doctors' knowledge regarding tuberculosis management in Lucknow, India: a public-private sector comparison. Public Health. 2009; 123:484-489.

23- Chen, S. Qiu, Z. Xu, L. Chen, J. Lin, $Y$ and Yang, Y. People groups' responses to SARS in the community. Chinese Rural Health Service Administration. 2003; 23:15-18.

24- Pawlowski, B. Atwal, $R$ and Dunbar, R. Sex Differences in Everyday Risk-Taking Behavior in Humans Evolutionary Psychology. 2008; 6: 29-42.

25- Zhong, B. Luo, W. Li, H. Zhang, Q. Liu, X. Li, W and Li, Y. Knowledge, attitudes, and practices towards 
COVID-19 among Chinese residents during the rapid rise period of the COVID-19 outbreak: a quick online cross-sectional survey. Int J Biol Sci. 2020;16 (10):1745-1752.

26- Ronald, O. Gaudencia, C. Godfrey, W. Dianah, $\mathbf{R}$ and Felix, $\mathrm{B}$. Coronavirus Disease-2019: Knowledge, Attitude, and Practices of Health Care Workers at Makerere
University Teaching Hospitals, Uganda. Public Health, https://doi.org/10.3389/fpubh.2020.0 01812020.

27- Ng, K. Poon, B. Kiat P. Shan Q. Loh, W and Wong Y. COVID-19 and the risk to health care workers: a case report. Ann Intern Med. 2020; doi: 10.7326/L20-0175. 